\title{
Endoglucanase and Total Cellulase from Newly Isolated Rhizopus oryzae and Trichoderma reesei: Production, Characterization, and Thermal Stability
}

\author{
Larine Kupski • Fernanda Arnhold Pagnussatt • \\ Jaqueline Garda Buffon • Eliana Badiale Furlong
}

Received: 22 May 2013 / Accepted: 15 September 2013 /

Published online: 4 October 2013

(C) Springer Science+Business Media New York 2013

\begin{abstract}
A multienzymatic complex production was evaluated, as well as endoglucanase and total cellulase characterization, during solid-state fermentation of rice industry wastes with Rhizopus oryzae CCT 7560 (newly isolated microorganism) and Trichoderma reesei QM 9414 (control). R. oryzae produced enzymes with higher activity at $15 \mathrm{~h}$ of fermentation (5.1 and $2.3 \mathrm{U} \mathrm{g}^{-1}$ to endoglucanase and total cellulase), while $T$. reesei produced them at $55 \mathrm{~h} \mathrm{(15.3} \mathrm{and} 2.8 \mathrm{U} \mathrm{g}^{-1}$ to endoglucanase and total cellulase). The optimum temperature for total cellulase and endoglucanase was $60{ }^{\circ} \mathrm{C}$. For Trichoderma and Rhizopus, the optimum $\mathrm{pH}$ was 5.0 and 6.0 for total cellulase and 6.0 and 5.0 for endoglucanase, respectively. The enzymes produced by Rhizopus presented higher stability at the temperature range evaluated $\left(25-100{ }^{\circ} \mathrm{C}\right)$; the endoglucanase $K_{\mathrm{M}}$ value was 20 times lower than the one found for Trichoderma. The characterization of the cellulolytic enzymes from the fungal species native of rice husk revealed that they can be more efficient than the genetically modified enzymes when rice husk and rice bran are used as substrates.
\end{abstract}

Keywords Solid-state fermentation - Cellulase - Biochemical characterization · Rice bran * Rice husk

\section{Introduction}

Degradation of lignocellulosic materials by microorganisms is a natural occurrence in many ecosystems. Currently, it has gained interest due to the difficult waste disposal of food industries, besides being rich in biomolecules of interest such as sugars with various degrees of polymerization [1].

Cellulases are inducible enzymes synthesized by microorganisms during their growth on cellulosic materials. Unlike most enzymes, the cellulase comprises an enzyme complex acting synergistically to degrade cellulose, including the endoglucanases (1,4- $\beta$-D-

L. Kupski $(\bowtie) \cdot$ F. A. Pagnussatt $\cdot$ J. G. Buffon $•$ E. B. Furlong

Laboratório de Ciência de Alimentos, Escola de Química e Alimentos, Universidade Federal do Rio

Grande - FURG, Rua Eng. Alfredo Huch, 475, Centro, 96201-900 Rio Grande, RS, Brazil

e-mail: larinekupski@yahoo.com.br 
glucanglucanohidrolase), exoglucanases (exo 1,4- $\beta$-D-glucan cellobiohydrolase), and $\beta$-Dglucosidases [2]. Cellulase has a broad range of applications in industrial sector. Recently, the role of cellulase in biorefinery got a significant attraction worldwide. Cellulolytic enzyme in cellulosic ethanol production from second-generation feedstocks plays a pivotal role in the success of bioethanol production [3].

Among the different techniques to obtain these enzymes, the solid-state fermentation (SSF) stands out for presenting advantages in relation to the submerged process, such as lower operating costs and high productivity $[4,5]$.

Proper selection of microorganism is one of the most important criteria to study SSF. Microorganisms must have a high efficiency in substrate conversion and allow the rapid release into the medium without producing toxic substances [6]. To meet this need, many microorganisms have been genetically modified to produce enzymes capable of degrading the substrate effectively. However, during the genetic manipulation of strains, side effects related to the modification of certain metabolic pathways may occur, leading to the production of fragile strains [7].

The potential application of an enzyme depends on its catalytic activity, i.e., its activity and stability under different physical conditions such as $\mathrm{pH}$ and temperature. Thus, the characterization of the enzyme is important to study the relevant parameters of an enzymatic process [8].

Based on that, this study aimed to compare a wild strain (Rhizopus oryzae CCT 7560), whose potential application was studied by [9], and a genetically modified strain (Trichoderma reesei QM 9414), regarding the enzyme production and the characteristics of the cellulolytic complex in terms of optimum $\mathrm{pH}$, temperature, and thermal stability.

\section{Materials and Methods}

\section{Fungi Isolates}

A strain of T. reesei QM 9414 and R. oryzae CCT 7560, obtained from André Tosello Culture Collection (CCT), was used for enzyme production. Periodic subculturing was performed on a potato dextrose agar medium (PDA) and incubated for 7 days at $30{ }^{\circ} \mathrm{C}$. The fungus was maintained in PDA slants at $4-8{ }^{\circ} \mathrm{C}$.

\section{Preparation of Inoculum}

Each petri dish containing $20 \mathrm{~mL}$ PDA was inoculated with spores that were scraped from the slopes into a Tween $80(0.2 \%)$ aqueous emulsion. They were kept for 7 days at $30^{\circ} \mathrm{C}$ until a new and complete sporulation of fungi. The spores were enumerated in a Neubauer chamber and used as a primary inoculum for further experiments.

\section{Production of Extracellular Enzymes}

To study the secretion of extracellular enzymes, rice husk and rice bran were used as substrates under optimized conditions (unpublished results).

The fermentation with $R$. oryzae was performed in tray bioreactors using $82.5 \%$ rice husk and $17.5 \%$ rice bran. The bioreactors were sterilized by autoclaving at $121{ }^{\circ} \mathrm{C}$ for $15 \mathrm{~min}$. After cooling, a nutrient solution containing (per liter) $20 \mathrm{~g} \mathrm{KH}_{2} \mathrm{PO}_{4}, 13 \mathrm{~g}\left(\mathrm{NH}_{4}\right)_{2} \mathrm{SO}_{4}, 3 \mathrm{~g}$ $\mathrm{CO}\left(\mathrm{NH}_{2}\right)_{2}, 3 \mathrm{~g} \mathrm{MgSO}_{4} \cdot 7 \mathrm{H}_{2} \mathrm{O}, 3 \mathrm{~g} \mathrm{CaCl}_{2}, 0,05 \mathrm{~g} \mathrm{FeSO}_{4} \cdot 7 \mathrm{H}_{2} \mathrm{O}, 0.0156 \mathrm{~g} \mathrm{MnSO}_{4} \cdot \mathrm{H}_{2} \mathrm{O}$, $0.002 \mathrm{~g} \mathrm{CoCl}_{2}$, and $0.014 \mathrm{~g} \mathrm{ZnSO}_{4} \cdot 7 \mathrm{H}_{2} \mathrm{O}$ and a solution containing $4.10^{6}$ spores $^{-1}$ were 
added to the bioreactors. A known volume of sterile water was added to achieve $30 \%$ moisture content.

The fermentation with T. reesei was performed in Erlenmeyer bioreactors using $100 \%$ rice husk. After sterilization of the bioreactors, the nutrient solution, the spore solution previously described, and sterile water to achieve $50 \%$ moisture content were added.

The products from both bioreactors were homogenized and incubated at $30{ }^{\circ} \mathrm{C}$ for 45 and $75 \mathrm{~h}$ for $R$. oryzae and $T$. reesei growth, respectively. The fermented biomass was sampled every $5 \mathrm{~h}$ for $25 \mathrm{~h}$ and then every $10 \mathrm{~h}$ until the end of fermentation. All samples were stored at $-18{ }^{\circ} \mathrm{C}$ until use.

To obtain the crude enzymatic extract, the fermented biomass was homogenized with $0.5 \% \mathrm{NaCl}(1: 5 \mathrm{w} / \mathrm{v})$ for $30 \mathrm{~min}$ at $25^{\circ} \mathrm{C}$, centrifuged, filtered, and stored at $5{ }^{\circ} \mathrm{C}$ until use.

Enzyme Assays

\section{Cellulolytic Activity}

The endoglucanase (EG) activity was assessed by measuring the release of reducing sugars in a reaction mixture containing the enzymatic extract and carboxymethyl cellulose $(0.5 \%)$ as a substrate in $50 \mathrm{mM}$ citrate buffer $(\mathrm{pH} 4.8)$ at $50^{\circ} \mathrm{C}$ for $10 \mathrm{~min}$. The total cellulase (TC) activity was determined by filter paper activity using a Whatman no. 1 filter paper $(1.0 \mathrm{~cm} \times 6.0 \mathrm{~cm}=$ $50 \mathrm{mg}$ ) as a substrate in $50 \mathrm{mM}$ citrate buffer $(\mathrm{pH} 4.8)$ at $50{ }^{\circ} \mathrm{C}$ for $30 \mathrm{~min}$ [10]. The reducing sugars released were determined by 3,5-dinitrosalicylic acid method (DNS) [11]. One unit of total cellulase and endoglucanase activities was defined as the amount of enzyme that released $1 \mu \mathrm{mol}$ of glucose per minute under the assay conditions [10].

\section{Activity of Other Carbohydrases}

The $\alpha$-amylase activity was determined in the reaction mixture containing the enzymatic extract and $0.5 \%$ starch in $0.1 \mathrm{M}$ citrate buffer at $50{ }^{\circ} \mathrm{C}$ for $5 \mathrm{~min}$. The residual starch content was determined quantitatively by iodometric method [12]. One unit of amylase activity was defined as the amount of enzyme required to hydrolyze $1 \mathrm{mg}$ starch per minute under the assay conditions.

The pectinolytic activity was determined in a reaction mixture containing the enzymatic extract and $0.5 \%$ pectin in $0.1 \mathrm{M}$ citrate buffer $(\mathrm{pH} 4.0)$ at $50{ }^{\circ} \mathrm{C}$ for $15 \mathrm{~min}$ [13]. The reducing sugars released were estimated quantitatively by the DNS method [10]. One unit of pectinase was defined as the amount of enzyme releasing $1 \mathrm{mg}$ galacturonic acid per minute under the assay conditions.

\section{Specific Activities}

The proteins extracted from the fermented biomass were determined using a standard curve of albumin ( 0.05 to $\left.0.4 \mathrm{mg} \mathrm{mL}^{-1}\right)$ [14]. The specific activity was determined by the ratio of activity (units per gram) to the soluble protein content of the extracts.

\section{Characterization of Endoglucanase and Total Cellulase}

The optimum temperature $\left(T_{\text {opt }}\right)$ for crude endoglucanases and total cellulases was defined from 10 to $80{ }^{\circ} \mathrm{C}$ under the conditions described above. The optimum $\mathrm{pH}$ for crude endoglucanases and total cellulases secreted during solid-state fermentation was estimated 
in the range of 3.0-8.0 using different assay buffers. The assays were conducted at $T_{\text {opt }}$ using carboxymethyl cellulose (CMC) solubilized in $50 \mathrm{mM}$ sodium acetate (pH 3.0-4.0), sodium citrate ( $\mathrm{pH}$ 5.0-6.0), sodium phosphate ( $\mathrm{pH} 7.0)$, or Tris- $\mathrm{HCl}(\mathrm{pH} 8.0)$ buffer. The enzyme activity at optimum temperature and $\mathrm{pH}$ was used to calculate the relative activity of the enzymes at different temperature and $\mathrm{pH}$ values.

The hydrolysis of CMC by $T$. reese $i$ and $R$. oryzae endoglucanases was characterized in terms of the Michaelis-Menten kinetic constants $\left(K_{\mathrm{M}}\right.$ and $\left.V_{\max }\right)$ using the Lineweaver-Burk (Eq. 1), Hanes-Woolf (Eq. 2), and Eadie-Hofstee (Eq. 3) plots by assaying the enzymes at CMC concentrations ranging from 0.04 to $0.4 \mathrm{mg} / \mathrm{mL}$, at optimum $\mathrm{pH}$ and temperature conditions.

$$
\begin{gathered}
\frac{1}{V}=\frac{K_{\mathrm{M}}}{V_{\max }} \frac{1}{[S]}+\frac{1}{V_{\max }} \\
\frac{[S]}{V}=\frac{1}{V_{\max }}[S]+\frac{K_{\mathrm{M}}}{V_{\max }} \\
V=V_{\max }-K_{\mathrm{M}} \frac{V}{[S]}
\end{gathered}
$$

The thermal stability of the crude endoglucanases and total cellulase secreted by T. reesei and $R$. oryzae was determined by the enzyme activity of the crude enzymatic extracts after incubation at different temperatures $\left(25,60,80\right.$, and $\left.100^{\circ} \mathrm{C}\right)$ and incubation periods $(0$ to $10 \mathrm{~h})$. The residual activities were determined under optimum $\mathrm{pH}$ and temperature conditions using the DNS method as previously described. In all cases, the initial activity was assumed to be $100 \%$ and used to calculate the percentage relative activities during the incubation period.

From a seminatural logarithmic plot of residual activity versus time, the deactivation rate constants $\left(K_{\mathrm{d}}\right)$ were calculated and the half-lives were estimated using Eq. 4. Half-life $\left(t_{1 / 2}\right)$ is defined as the time taken for the residual activity to reach $50 \%$ [15].

$$
t_{1 / 2}=\frac{\ln 2}{K_{\mathrm{d}}}
$$

The decimal reduction time, or $D$ value, was determined by Eq. 5 and is defined as the time, at a constant temperature and pressure, required to reduce $90 \%$ of the initial activity [16].

$$
D=\frac{2,303}{K_{\mathrm{d}}}
$$

In order to determine the thermodynamic parameters, the enthalpy, Gibbs free energy, and entropy of deactivation were calculated for given temperature values according to the Eqs. 6, 7 , and 8 [17].

$$
\begin{gathered}
\Delta H=E_{\mathrm{d}}-R T \\
\Delta G^{*}=-R T \ln \frac{K_{\mathrm{d}} h}{K T} \\
\Delta S^{*}=\frac{\left(\Delta H^{*}-\Delta G^{*}\right)}{T}
\end{gathered}
$$


where $R$ is the universal gas constant, $T$ is the absolute temperature, $h$ is Planck's constant $\left(6.6262 \times 10^{-34} \mathrm{~J} \mathrm{~s}\right)$, and $k$ is Boltzmann's constant $\left(1.3806 \times 10^{-23} \mathrm{~J} \mathrm{~K}^{-1}\right)$.

\section{Results and Discussion}

Degradation of waste from the rice industry can be best performed by native microorganisms. Thus, $R$. oryzae from rice husk and $T$. reesei were cultivated in rice husk and rice bran to produce a multienzymatic complex of carbohydrases whose specific activity profile is shown in Fig. 1.

The microorganism $R$. oryzae provided a more rapid assimilation of nutrients from the waste of the rice industry (husk and rice bran), possibly because it had been isolated from rice husk, resulting in faster production of the enzymes in question, exhibiting a peak production at $15 \mathrm{~h}$ of process (Fig. 1a). In contrast, T. reesei exhibited a delayed production profile (55 h of process) as compared to $R$. oryzae, proving that the wild strain is best adapted to the fermentation conditions. This behavior can be also explained by the differences between the microorganism classes: $R$. oryzae is a zygomycete fungus with nonseptate hyphae that facilitate fungal propagation while $T$. reesei is classified as ascomycetes with sexual spores stored in cells, and such conformity generates a lower sporulation rate [18].

The enzyme production profile indicates that in a given fermentation period for each microorganism, there is a reduced production of carbohydrases or even an enzyme stabilization due to the reduction of carbon source needed for enzyme induction (starch, pectin, and cellulose) [13]. Among the enzymes produced in the present study, endoglucanase and pectinase were secreted in higher levels in both fermentation processes. The total cellulase and amylase were secreted in a lesser extent, presenting similar values for both isolates. This occurred because endoglucanase and pectinase are endoenzymes, so they are produced in a higher content to decrease the polymer chain and consequently provide a faster energy source to attend the demand of the higher biomass production phase.

The crude extract confers advantages in relation to the purified form, including lower operation cost, since sophisticated techniques for recovery and purification of enzymes are not necessary to the biorefinery or waste treatment. Moreover, since the crude extract has a multienzymatic complex of carbohydrases (amylase, cellulase, and pectinase), it may be used to increase the yield of hydrolysis of lignocellulosic biomass into fermentable sugars due to the synergistic action of enzymes present in the biomass. In addition, these enzymes can be used in natura in the substrate, without previous chemical treatment.

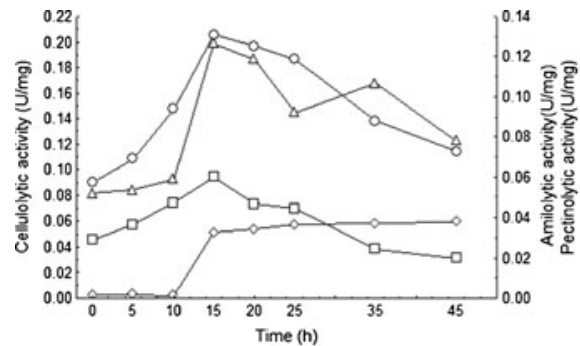

(a)

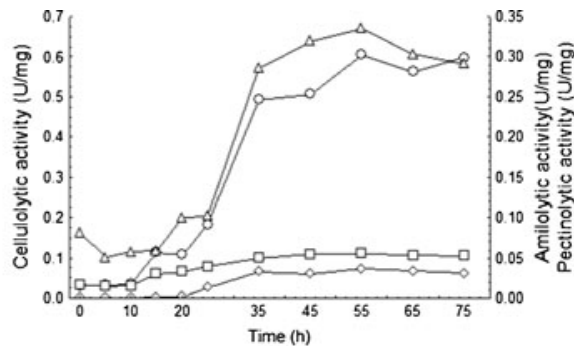

(b)

Fig. 1 Enzymatic production of endoglucanase (white circles), total cellulase (white squares), amylase (white diamonds), and pectinase (white triangles) during solid-state fermentation with $R$. oryzae (a) and T. reesei (b) 
The complex produced by $R$. oryzae showed higher endoglucanase $\left(0.206 \mathrm{mg}_{\text {protein }}{ }^{-1}\right)$ and total cellulase $\left(0.094 \mathrm{U} \mathrm{mg}_{\text {protein }}{ }^{-1}\right)$ activities in $15 \mathrm{~h}$ of fermentation, which correspond to 0.92 and $0.43 \mathrm{U} \mathrm{mL}^{-1}$ and 5.08 and $2.33 \mathrm{U}_{\text {dry biomass }}{ }^{-1}$, respectively. The complex produced by $T$. reesei presented higher endoglucanase and total cellulase activities in $55 \mathrm{~h}$ of fermentation, with values of 0.61 and $0.11 \mathrm{U} \mathrm{mg}_{\text {protein }}{ }^{-1}$, which correspond to 0.97 and $0.32 \mathrm{U} \mathrm{mL}^{-1}$ and 15.26 and $2.78 \mathrm{U}_{\mathrm{dry}}$ biomass $^{-1}$, respectively.

Enzyme production by T. reesei RUT C-30 on rice husk under different treatments was studied by Sun et al. [19], who obtained the highest production of total cellulase after 12 days of fermentation, with values of 0.16 and $0.12 \mathrm{U} \mathrm{mL}^{-1}$ for alkali-treated rice husks and rice husk powder, respectively. These values are approximately 56.3 and $67.5 \%$ lower than the values found in the present study (substrate without chemical treatment) for T. reesei and $R$. oryzae, respectively.

The application of ultrasound to treat the rice husk used as a fermentation substrate in SSF with Aspergillus japonicas presented, after 7 days, endoglucanase activity similar to the one found in this study using untreated substrate [20]. Therefore, the production cost from the species of the present study would be lower. The enzymatic production profile of Aspergillus oryzae MTCC 1846 was accessed under submerged cultivation conditions using Saccharum spontaneum as a primary carbon source [21]. The endoglucanase and total cellulase activities were 1.25 and $0.85 \mathrm{IU} \mathrm{mL}^{-1}$, being similar to those observed for $R$. oryzae and T. reesei. In the present study, the extract concentration would not be necessary and the space for the production could be smaller.

The peak of endoglucanase production by $R$. oryzae at $15 \mathrm{~h}$ of fermentation shows a high cellulolytic potential, thus presenting benefits for producing the enzyme in large-scale production. In view of this, biochemical characterization of cellulolytic enzymes present in the complex (endoglucanase and total cellulase) produced by wild strains (R. oryzae) and genetically modified strains ( $T$. reesei) was accomplished in order to secure the advantage of using $R$. oryzae as a fermentation agent of wastes from the rice industry and to apply this substrate as a source to alcohol production.

\section{Optimum Temperature and $\mathrm{pH}$}

The effect of temperature on the activity of EG and TC was similar, once the activity increased with increasing the temperature up to $60{ }^{\circ} \mathrm{C}$, and thereafter, it declined. In the literature, other microorganisms have shown resistance to temperatures above $50{ }^{\circ} \mathrm{C}$, such as Bacillus and Geobacillus at 70 and $75^{\circ} \mathrm{C}$, respectively [22], Aspergillus niger at $45^{\circ} \mathrm{C}$ [23], and Melanocarpus sp. in the range between 50 and $70{ }^{\circ} \mathrm{C}$ [24].

The effect of $\mathrm{pH}$ on the ionization of the active center at $\mathrm{pH}$ values of 3 to 8 and at the optimum reaction temperature $\left(60{ }^{\circ} \mathrm{C}\right)$ (Fig. 2b) showed little variation in the cellulolytic activities of the complexes produced by both microorganisms, indicating that this $\mathrm{pH}$ range can be used without significant loss of enzyme activity. The optimum $\mathrm{pH}$ for the $\mathrm{EG}$ produced by $T$. reesei was 6.0 , while $R$. oryzae secreted the enzyme at $\mathrm{pH}$ 5.0. Optimum $\mathrm{pH}$ values from 4.5 to 6.0 are common for fungal cellulases secreted by Chaetomium thermophilum [25], Penicillium purpurogenum [26], and T. reesei [27].

\section{Thermal Stability}

The regression between residual activity and incubation time at each temperature is summarized in Tables 1 and 2. 


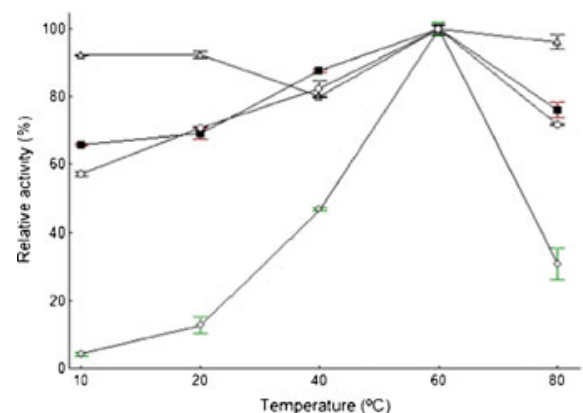

(a)

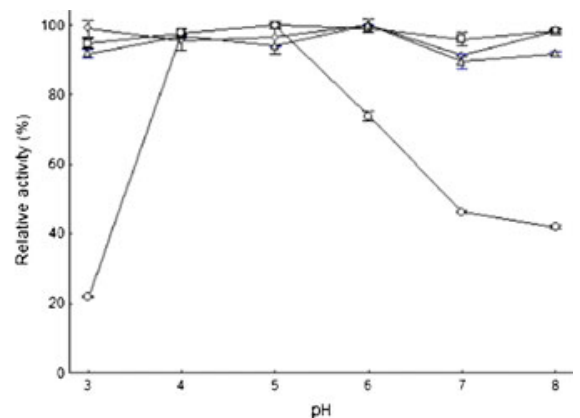

(b)

Fig. 2 Temperature (a) and $\mathrm{pH}$ (b) effect on $\mathrm{R}$. oryzae endoglucanase (black squares with error bars) and total cellulase (white triangles with error bars) activities and T. reesei endoglucanase (white diamonds with error bars) and total cellulase (white circles with error bars) activities

High temperatures increase the inactivation rate and half-life and decrease the $D$ value [16] because of changing the native conformation of the enzyme.

T. reesei has been shown to produce less thermostable cellulases than the newly isolated $R$. oryzae, which produced more stable enzymes, presenting values of $0.016 \mathrm{~h}^{-1}, 43.3 \mathrm{~h}$, and $143.9 \mathrm{~h}$ for $K_{\mathrm{d}}, t_{1 / 2}$, and $D$ value at $100{ }^{\circ} \mathrm{C}$, respectively.

At $60{ }^{\circ} \mathrm{C}, t_{1 / 2}$ for the EG produced by $R$. oryzae and $T$. reesei was 53.3 and $7.2 \mathrm{~h}$, respectively. These values were 13 and 1.8 times higher than those found for the EG secreted by Aspergillus fumigatus $(4.1 \mathrm{~h})$ [17] and 150 and 20 times higher than those found for Fusarium oxysporum $(0.35$ h) [28], thus demonstrating a higher thermal stability of the enzymes of this study.

Tables 1 and 2 showed the data used to calculate the activation energy of denaturation $\left(E_{\mathrm{a}(\mathrm{D})}\right)$ through the Arrhenius plot (Fig. 3). The results of $E_{\mathrm{a}(\mathrm{D})}$ for endoglucanase and total cellulase produced by $R$. oryzae and $T$. reesei were 17.7 and $16.3 \mathrm{~kJ} \mathrm{~mol}^{-1}$ and 66.3 and $35.4 \mathrm{~kJ} \mathrm{~mol}^{-1}$, respectively.

Table 1 Thermal denaturation of the crude endoglucanase and total cellulase from $R$. oryzae ant their kinetic and thermodynamic parameters

\begin{tabular}{lcccccc}
\hline Temperature $\left({ }^{\circ} \mathrm{C}\right)$ & $K_{\mathrm{d}}\left(\mathrm{h}^{-1}\right)$ & $t_{1 / 2}(\mathrm{~h})$ & $D$ value $(\mathrm{h})$ & $\Delta H\left(\mathrm{~kJ} \mathrm{~mol}^{-1}\right)$ & $\Delta G\left(\mathrm{~kJ} \mathrm{~mol}^{-1}\right)$ & $\Delta S\left(\mathrm{~kJ} \mathrm{~mol}^{-1} \mathrm{~K}^{-1}\right)$ \\
\hline Endoglucanase & & & & & & \\
$\quad 25$ & 0.011 & 63.0 & 209.4 & 15.2 & 104.4 & -0.30 \\
60 & 0.013 & 53.3 & 177.2 & 14.9 & 116.6 & -0.31 \\
80 & 0.032 & 21.7 & 72.0 & 14.8 & 121.1 & -0.30 \\
100 & 0.044 & 15.8 & 52.3 & 14.6 & 127.1 & -0.30 \\
Total cellulase & & & & & & -0.31 \\
25 & 0.004 & 173.3 & 575.8 & 13.8 & 107.0 & -0.32 \\
60 & 0.006 & 115.5 & 383,8 & 13.5 & 118.7 & -0.32 \\
80 & 0.009 & 77.0 & 255.9 & 13.4 & 124.8 & -0.31 \\
100 & 0.016 & 43.3 & 143.9 & 13.2 & 130.3 &
\end{tabular}

$K_{d}$ inactivation rate constants, $t_{1 / 2}$ half-life, $D$ decimal reduction time, $\Delta H$ enthalpy, $\Delta G$ Gibbs free energy, $\Delta S$ entropy 
Table 2 Thermal denaturation of the crude endoglucanase and total cellulase from T. reesei and their kinetic and thermodynamic parameters

\begin{tabular}{lrrrccc}
\hline Temperature $\left({ }^{\circ} \mathrm{C}\right)$ & $K_{\mathrm{d}}\left(\mathrm{h}^{-1}\right)$ & $t_{1 / 2}(\mathrm{~h})$ & $D$ value $(\mathrm{h})$ & $\Delta H\left(\mathrm{~kJ} \mathrm{~mol}^{-1}\right)$ & $\Delta G\left(\mathrm{~kJ} \mathrm{~mol}^{-1}\right)$ & $\Delta S\left(\mathrm{~kJ} \mathrm{~mol}^{-1} \mathrm{~K}^{-1}\right)$ \\
\hline Endoglucanase & & & & & & \\
25 & 0.017 & 40.8 & 135.5 & 63.8 & 103.4 & -0.13 \\
60 & 0.096 & 7.2 & 24.0 & 63.5 & 111.0 & -0.14 \\
80 & 1.462 & 0.5 & 1.6 & 63.4 & 109.9 & -0.13 \\
100 & 2.826 & 0.2 & 0.8 & 63.2 & 114.2 & -0.14 \\
Total cellulase & & & & & & \\
25 & 0.052 & 13.3 & 44.3 & 32.9 & 100.6 & -0.23 \\
60 & 0.067 & 10.3 & 34.4 & 32.6 & 112.0 & -0.24 \\
80 & 0.370 & 1.9 & 6.2 & 32.4 & 113.9 & -0.23 \\
100 & 0.897 & 0.8 & 2.6 & 32.3 & 117.8 & -0.23 \\
\hline
\end{tabular}

$K_{d}$ inactivation rate constants, $t_{1 / 2}$ half-life, $D$ decimal reduction time, $\Delta H$ enthalpy, $\Delta G$ Gibbs free energy, $\Delta S$ entropy

The enzymes produced by $T$. reesei showed higher $E_{\mathrm{d}}$ values, which was an expected behavior, since reactions having high activation energy increase the reaction rate at temperatures above those of low-energy reactions [29]. Therefore, increasing temperature provides a higher denaturation of the enzymes secreted by $T$. reesei, which is consistent with the shorter half-life and $D$ value found for these enzymes.

\section{Thermodynamic Parameters}

According to [29], the thermal inactivation occurs in two steps:

$$
\mathrm{N} \leftrightarrow \mathrm{U} \leftrightarrow \mathrm{I}
$$

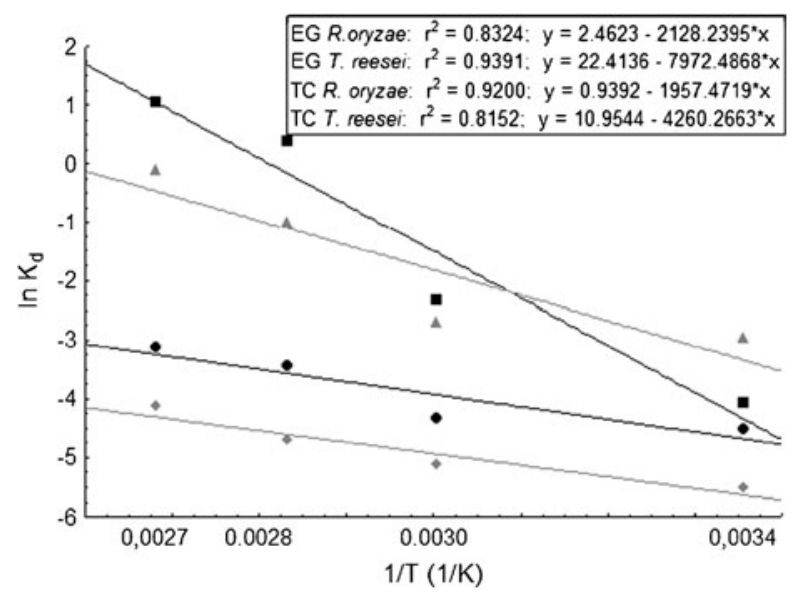

Fig. 3 First-order Arrhenius plot for the denaturation energy $\left(E_{\mathrm{a}(\mathrm{D})}\right)$ of the crude endoglucanase from $R$. oryzae (black circles) and T. reesei (black squares) and total cellulase from $R$. oryzae (gray diamonds), $T$. reesei (gray triangles). Inset: Arrhenius equations and their determination coefficient $\left(r^{2}\right)$ 
Where $\mathrm{N}$ is the native, $\mathrm{U}$ is the unfolded enzyme which could be reversibly refolded upon cooling, and $\mathrm{I}$ is the inactivated enzyme formed after prolonged exposure to heat.

To better understand the denaturation mechanism, the parameters enthalpy $(\Delta H)$ and entropy $(\Delta S)$, which provide the number of noncovalent bonds broken and the change in the disorder enzyme/solvent associated with the transition state [30] were determined.

As shown in Tables 1 and 2, $\Delta S$ values were negative, which represents an insignificant disorder, since thermal inactivation did not change the tertiary structure of the enzyme, possibly because the hydrogen interactions responsible for the active site structure are still present [31]. This behavior was similar to $\beta$-glucosidase produced by Kluyveromyces marxianus [28]. $\Delta H$ values for the enzymes produced by $R$. oryzae ranged between 13.8 and $15.2 \mathrm{~kJ} \mathrm{~mol}^{-1}$, and for T. reesei, the values varied from 32.3 to $63.8 \mathrm{~kJ} \mathrm{~mol}^{-1}$, indicating that more covalent interactions were broken on $T$. reesei enzymes with the increase in temperature, i.e., higher denaturation occurred.

The Gibbs free energy $(\Delta G)$ is the most reliable thermodynamic parameter to indicate the enzymatic stability [17]. A small or negative value of this variable indicates thermal denaturation. $\Delta G$ values reported in the literature for EG produced by $A$. oryzae and $A$. fumigatus are in the order $107 \mathrm{~kJ} \mathrm{~mol}^{-1}$ at $50-80{ }^{\circ} \mathrm{C}$ [17] and $100 \mathrm{~kJ} \mathrm{~mol}^{-1}$ at $50{ }^{\circ} \mathrm{C}$ [32], respectively. The enzymes produced by $R$. oryzae showed higher $\Delta G$ values than those produced by $T$. reesei, confirming their greater heat stability.

\section{Kinetic Characterization of Endoglucanases}

Among the three graphical methods to determine the enzyme kinetic parameters, the most widely used is the linearization of Lineweaver-Burk, which defines the reaction rate as a function of the inverse substrate concentration under certain conditions [29]. As can be seen in Table 3, the values found by this method were similar to those found by the method proposed by Hanes-Woolf, which correlates the ratio of the reaction velocity to the substrate concentration. Both methods exhibited the highest correlation $\left(R^{2}\right)$ for the microorganisms of the present study. Therefore, it can be concluded that both methods are more acceptable than the Eadie-Hofstee method because of the similarity of the kinetic parameters. The method of Eadie-Hofstee may cause a greater error in estimating kinetic parameters since the variable velocity is used to plot the two axes, which is an experimental measure, thus may have errors inherent to the method used.

The $K_{\mathrm{M}}$ for the endoglucanase by $T$. reesei was 20 times higher than that secreted by $R$. oryzae, indicating that it has lower affinity for the substrate used (CMC).

The values obtained in this study were lower than those reported in the literature, which were 3.1 and $1.1 \mathrm{mg} \mathrm{mL}^{-1}$ for Bacillus and Geobacillus, respectively [21]; $1.15 \mathrm{mg} \mathrm{mL}^{-1}$ for

Table $3 K_{\mathrm{M}}$ and $V_{\max }$ values for different regression methods

\begin{tabular}{|c|c|c|c|c|c|c|}
\hline \multirow[t]{2}{*}{ Method } & \multicolumn{3}{|c|}{ Rhizopus oryzae } & \multicolumn{3}{|c|}{ Trichoderma reesei } \\
\hline & $K_{\mathrm{M}}(\mathrm{mg} / \mathrm{mL})$ & $V_{\max }(\mathrm{U} / \mathrm{g})$ & $R^{2}$ & $K_{\mathrm{M}}(\mathrm{mg} / \mathrm{mL})$ & $V_{\max }(\mathrm{U} / \mathrm{g})$ & $R^{2}$ \\
\hline Lineweaver-Burk & 0.01 & 8.1 & 0.82 & 0.20 & 5.8 & 0.97 \\
\hline Hanes-Woolf & 0.01 & 8.0 & 0.99 & 0.28 & 7.0 & 0.95 \\
\hline Eadie-Hofstee & 0.01 & 8.0 & 0.79 & 0.58 & 6.1 & 0.84 \\
\hline
\end{tabular}

$K_{M}$ Michaelis-Menten constant, $V_{\max }$ maximum catalytic velocity, $R^{2}$ correlation 
P. purpurogenum [26]; 0.84 and $0.83 \mathrm{mg} \mathrm{mL}^{-1}$ for $T$. reesei and A. oryzae, respectively [23, 27]; and $4.6 \mathrm{mg} \mathrm{mL}^{-1}$ for C. thermophilum [25].

The characterization of cellulolytic enzymes secreted by fungal species native to rice husk revealed that the native organisms can be more efficient than those genetically modified when using waste from the rice industry as a substrate. Studies on molecular characterization of the species and enzyme purification for more specific purposes have been conducted.

\section{Conclusion}

During solid-state fermentation of rice industry wastes, the microorganisms $R$. oryzae and $T$. reesei produced a multienzymatic complex, presenting endoglucanase activities of 5.1 and 15.3 U g, respectively. The microorganism $R$. oryzae isolated from rice husk produced cellulolytic enzymes in a shorter period of time (five times) and higher thermal stability (1080 times) as compared to T. reesei at different temperatures. The results found in this study support the search for different fungal strains and the use of wild strains capable of degrading industry wastes to enzymatic production.

\section{References}

1. Papinutti, V. L., \& Forchiassin, F. (2007). Journal of Food Engineering, 81, 54-59.

2. Lee, Y. J., Kim, B. K., Lee, B. H., Jo, K. I., Lee, N. K., Chung, C. H., Lee, Y. C., \& Lee, J. W. (2008). Bioresource Technology, 99, 378-386.

3. Chandel, A. K., Chandrasekhar, G., Silva, M. B., \& Silvério da Silva, S. (2012). Critical Reviews in Biotechnology, 32, 187-202.

4. Raghavarao, K. S. M. S., Ranganathan, T. V., \& Karanth, N. G. (2003). Biochemical Engineering Journal, 13, 127-135.

5. Maurya, D. P., Singh, D., Pratap, D., \& Maurya, J. P. (2012). Journal of Environmental Biology, 33, 5-8.

6. Singhania, R. R., Sukumaran, R. K., Patel, A. K., Larroche, C., \& Pandey, A. (2010). Enzyme and Microbial Technology, 46, 541-549.

7. Andersson, S. G. E., \& Kurland, C. G. (1998). Trends in Microbiology, 6, 263-268.

8. Heidtmann, R. B., Duarte, S. H., Pereira, L. P., Braga, A. R. C., \& Kalil, S. J. (2012). Brazilian Journal of Food Technology, 15, 41-49.

9. Oliveira, M. S., Kupski, L., Feddern, V., Cipolatti, E. P., Badiale-Furlong, E., \& Souza-Soares, L. A. (2010). CyTA- Journal of Food, 8, 229-236.

10. Ghose, T. K. (1987). Pure and Applied Chemistry, 59, 257-268.

11. Miller, G. L. (1959). Analytical Chemistry, 31, 426-429.

12. Baraj, E., Garda-Buffon, J., \& Badiale-Furlong, E. (2010). Influence of the trichothecenes DON and T-2 toxin in malt aminolitic enzymes activity. Brazilian Journal of Food Technology, 53, 505-511.

13. Rodríguez-Fernández, D. E., Rodríguez-León, J. A., Carvalho, J. C., Sturm, W., \& Soccol, C. R. (2011). Bioresource Technology, 102, 10657-10662.

14. Lowry, O. H., Rosenbrough, M. J., Farr, A. L., \& Randall, R. J. (1951). The Journal of Biological Chemistry, 193, 265-275.

15. Siddiqui, K. S., Azhar, M. J., Rashid, M. H., \& Rajoka, M. I. (1997). Folia Microbiologica, 42, 312-318.

16. Balsan, G., Astolfi, V., Benazzi, T., Meireles, M. A. A., Maugeri, F., Di Luccio, M., Prá, V. D., Mossi, A. J., Treichel, H., \& Mazutti, M. A. (2012). Bioprocess and Biosystems Engineering, 35, 1229-1237.

17. Saqib, A. A. N., Hassan, M., Khan, N. F., \& Baig, S. (2010). Process Biochemistry, 45, 641-646.

18. Griffin, D. H. (1993). Fungal physiology (2nd ed.). New York: Wiley.

19. Sun, W. C., Cheng, C. H., \& Lee, W. C. (2008). Process Biochemistry, 43, 1083-1087.

20. Yang, C. Y., Sheih, I. C., \& Fang, T. J. (2012). Ultrasonics Sonochemistry, 19, 687-691.

21. Chandel, A. K., Narasu, M. L., Chandrasekhar, G., Manukyam, A., \& Venkateswar Rao, L. (2009). Bioresource Technology, 100, 2404-2410. 
22. Rastogi, G., Bhalla, A., Adhikari, A., Bischoff, K. M., Hughes, S. P., Christopher, L. P., \& Sani, R. K. (2010). Bioresource Technology, 101, 8798-8806.

23. Begum, M. F., \& Absar, N. (2009). Mycobiology, 37, 121-127.

24. Kaur, J., Chadha, B. S., Kumar, B. A., \& Saini, H. S. (2007). Bioresource Technology, 98, 74-81.

25. Li, D. C., Lu, M., Li, Y. L., \& Lu, J. (2003). Enzyme and Microbial Technology, 33, 932-937.

26. Lee, K. M., Jeya, M., Joo, A. R., Singh, R., Kim, I. W., \& Lee, J. L. (2010). Enzyme and Microbial Technology, 46, 206-211.

27. Qin, Y., Wei, X., Song, X., \& Qu, Y. (2008). Journal of Biotechnology, 135, 190-195.

28. Shuyan, L., Xinyuan, D., Xuemei, L., \& Peiji, G. (2006). Chinese Science Bulletin, 51, 191-197.

29. Whitaker, J. R. (1995). Principles of enzymology for the food sciences (2nd ed.). New York: Marcel Dekker.

30. de Ortega, N., Diego, S., Perez-Mateos, M., \& Busto, M. D. (2004). Food Chemistry, 88, 209-217.

31. Ustok, F. I., Tari, C., \& Harsa, S. (2010). Food Chemistry, 119, 1114-1120.

32. Javed, M. R., Rashid, M. H., Nadeem, H., Riaz, M., \& Perveen, R. (2009). Applied Biochemistry and Biotechnology, 157, 483-497. 